Ірина ЧМЕЛИК, orcid.org/0000-0001-8352-6873 кандидат мистецтвознавства, доцент, доиент кафедри дизайну і теорії мистеитва Прикарпатського національного університету імені Василя Стефаника (Івано-Франківськ, Украӥна) irynachmelyk@gmail.com

\title{
МЕМОРІАЛЬНИЙ КОМПЛЕКС «ДЕМ'ЯНІВ ЛАЗ» В ІВАНО-ФРАНКІВСЬКУ: ОСОБЛИВОСТІ АРХІТЕКТУРНО-ЛАНДШАФТНОГО ПРОСТОРУ ТА МУЗЕЙНОї ЕКСПОЗИЦЇ̈
}

\begin{abstract}
Стаття присвячена висвітленню складної й неоднозначної проблеми української історії, а саме: створення пам'ятних місиь для належного вшанування жертв радянського тоталітаризму. Прихід у 1939 р. на Західну Україну окупаційної радянської влади призвів до масового терору у вигляді арештів, засуджень, катувань та розстрілів усіх, хто був незгідний із репресивною політикою комуністичної партії. Одним із таких місиь страт i масових захоронень є урочище "Дем'янів Лаз» на околичі Івано-Франківська, де на початку 2000-х рр. було відкрито меморіальний музей. Мета статті полягає у висвітленні умов створення й функиіонування меморіального комплексу "Дем'янів Лаз», у розкритті його архітектурно-мистецьких особливостей, ландшафтного дизайну, колекиї загалом та окремих артефактів; у виокремленні ролі авторів проєкту, громадських інституичій $і$ активістів у формуванні сучасного музейного простору та популяризації його діяльності, зокрема вклад дизайн-фірми «Реклама-ичентр» у наданні актуального вигляду музейній експозииії. Авторка розглядає історію створення музею, наводить факти, щуо містяться в різних джерелах, узагальнює інформацію й свідчення науковиів, краєзнавиів, очевидиів, а також тих, хто проводив розкопки на місці масових захоронень жертв тоталітарного режиму на Прикарпатті у 1989 роиі. Дослідниия зосереджує увагу на аналізі архітектурних споруд, зокрема каплиці-дзвіниці, ландшафтного дизайну та експозииї музейного комплексу. Результати проведеної наукової розвідки свідчать про те, щчо меморіальний музей «Дем'янів Лаз», створений украӥнськими художниками й дизайнерами відповідно до розуміння сутності функиіонування сучасного музейного простору, є доволі виразним, концептуально змістовним ансамблем, наочно втілює ідею збереження людської пам'яті про складні й жахливі сторінки начіональної історії ХХ століття.
\end{abstract}

Ключові слова: музей, меморіальний комплекс, «Дем'янів лаз», експозиція, жертви, тоталітарний режим.

Iryna CHMELYK, orcid.org/0000-0001-8352-6873 Candidate of Fine Art, Associate Professor at the Department of Design and Theory of Art Vasyl Stefanyk Precarpathian National University (Ivano-Frankivsk, Ukraine) irynachmelyk@gmail.com

\section{MEMORIAL COMPLEX "DEMYANIV LAZ" IN IVANO-FRANKIVSK: FEATURES OF ARCHITECTURAL, LANDSCAPE AREA AND MUSEUM EXHIBITION}

The article is devoted to the coverage of a complex and significant page of Ukrainian history, namely, the creation of the memorial sites for the proper honoring of the victims of the Soviet totalitarianism. Arrival in 1939 of Soviet occupation in the West Ukraine led to the mass terror in the form of arrests, convictions, torture and executions of all those who disagreed with repressive policy of the Communist Party. One such place of execution and mass graves is the area called "Demyaniv Laz" situated on the outskirts of Ivano-Frankivsk, where the memorial museum was opened in the early 2000s. The purpose of the article Is to highlight the conditions of creation and operation of the memorial complex "Demyaniv Laz", to disclose its architectural and artistic features, landscape design, collection of general and individual artifacts, to highlight the role of project authors, public institutions and activists in the formation of the modern museum area and popularization of its activity, in particular, the contribution of the design firm "Reclama Center" in providing a current form of the museum exposition. The author considers the history of the museum, provides the facts that are contained in different sources, summarizes the information and evidence of the 
scientists, local historians, eyewitnesses, as well as those who conducted excavations at the site of mass burials of victims of the totalitarian regime in Prykarpattia in 1989. The researcher focuses on the analysis of the architectural structures, in particular on chapels- bell tower, landscape design and exposition of the museum complex. The results of the scientific research indicate that the memorial museum "Demyaniv Laz", created by Ukrainian artists and designers in accordance with the understanding of the essence of the functioning of the modern museum area, is quite expressive, conceptually meaningful and clearly supports the idea of preserving human memory of the complex and terrible pages of the national history of the twentieth century.

Key words: museum, memorial complex, "Demyaniv Laz”, exposition, victims, totalitarian regime.

Постановка проблеми. Роздумуючи над циклічністю цивілізаційних процесів, суспільних явищ та подій, серед них відзначимо такі, що не повинні повторитися в жодному разі. Щоб цього не сталося, свою історію потрібно пам'ятати. XX століття по нашій землі пройшлося двома руйнівними світовими війнами, тоталітарним режимом, коротким періодом національного пробудження, «відродження», раптом, у першому двадцятиріччі XXI століття над українською нацією знову нависла небезпека. Зайве говорити про актуальність такого дослідження, бо в складних суспільно-політичних умовах, в яких нині опинилася Україна, необхідно пригадати реалії кривавого тоталітаризму з метою відновлення історичної справедливості та застерігаючи від колишніх помилок. Прихід на Західну Україну окупаційної радянської влади призвів до масових арештів, засуджень і катувань місцевого населення, а поспішний відхід під тиском наступаючої німецької армії на початку Другої світової війни змушував радянське керівництво проводити каральні заходи швидко, фізично знищуючи тих, хто був не згідний з репресивною політикою компартії. Таким місцем страт $\mathrm{i}$ масових захоронень $\epsilon$ урочище «Дем'янів Лаз» на околиці Івано-Франківська, який інколи називають прикарпатським Бабиним Яром чи галицькою Биківнею. Тут на початку 2000-х рр. було відкрито меморіальний музей.

Аналіз досліджень. Джерелами наукової розвідки стали як публікації місцевої періодики так і матеріали інтернет-ресурсів, де знаходимо відомості про репресії радянського тоталітарного режиму, сам музей і його експозицію (Добош, 2015; Кіпіані, 2010; Меморіальний комплекс «ДЕМ'ЯНІВ ЛАЗ»; Як проводили розкопки у 1989 році в Дем'яновому лазі біля Івано-Франківська). Актуальною й важливою є інформація краєзнавців, істориків, місцевих дослідників, спогади очевидців давніх подій й тих, хто власноручно проводив розкопки (Возняк, 2010; Зятьєв, 2010; Кіпіані, 2010; Як проводили розкопки у 1989 році в Дем'яновому лазі біля Івано-Франківська). Найбільш вагомими для нас стали друковані праці і спогади Романа Круцика ${ }^{1}$, який, зокрема, проводив розкопки, був ініціатором створення меморіального музею «Дем'янів Лаз», а також записав відео екскурсію по ньому (Круцик, 2009; Круцик, БРВ). Він також був одним із перших, чиї дослідницькі матеріали були опубліковані у місцевій газеті «Галичина» у 1990-1991 роках. Незважаючи на великий обсяг свідчень очевидців, знайдених та розсекречених матеріалів, історичних документів, у виданнях та періодиці майже відсутня інформація про мистецькі особливості споруд комплексу, його ландшафтний дизайн, принципи формування музейної експозиції, що й зумовило необхідність дослідження саме цих аспектів і спонукало до написання статті.

Мета статті полягає у висвітленні умов створення й функціонування меморіального комплексу «Дем'янів Лаз», у розкритті його архітектурно-мистецьких особливостей, ландшафтного дизайну, колекції загалом та окремих артефактів; у виокремленні ролі авторів проєкту, громадських інституцій і активістів у формуванні сучасного музейного простору та популяризації його діяльності, зокрема вклад дизайн-фірми «Реклама-центр» у наданні актуального вигляду музейній експозиції.

Виклад основного матеріалу. Висвітлюючи архітектурно-мистецькі особливості вказаного об'єкту, необхідно бодай коротко зупинитися на історії перепоховань. У жовтні 2009 р. відбулося урочисте відкриття оновленого меморіального комплексу «Дем'янів Лаз» та однойменного музею. Урочистості проходили за участі президента України Віктора Ющенка в межах відзначення 20-ї річниці перепоховання останків жертв

\footnotetext{
Рома́н Кру́цик - Народний депутат України 2-го скликання, голова Київської міської організації Українського історикопросвітницького правозахисного благодійного товариства «Меморіал» ім. В. Стуса, голова першого в ІваноФранківській області осередку Товариства «Меморіал»; пізніше - голова Івано-Франківської обласної організації товариства «Меморіал». Працював над дослідженням масових поховань жертв комуністичних репресій в урочищі Дем'янів Лаз на Івано-Франківщині, був одним із засновників Конгресу українських націоналістів (КУН), очолив ІваноФранківську обласну організацію КУН. Згодом виконував обов'язки заступника голови Українського інституту національної пам'яті, сприяв створенню та став директором Музею радянської окупації України в Києві.
} 
комуністичного режиму, таємно захоронених органами НКВД на початку літа 1941 р., поблизу урочища Дем’янів Лаз.

Розкопки розпочалися у серпні 1989 р. $з$ ініціативи Івано-Франківського обласного товариства «Меморіал» на території Пасічнянського лісу за межами Івано-Франківська. 21 вересня було знайдено першу могилу. Пошукові роботи тривали майже 40 днів зі залученням громадських активістів та мешканців навколишніх сіл, зі дотриманням тодішніх радянських законів, за присутності понятих та свідків. Для розуміння ситуації, за якої відбувалися розкопки, вартісними є свідчення одного 3 учасників розкопок, відомого в Івано-Франківську художника Степана Каспрука: «Йшла сильна боротьба, ці КДБісти перешкоджали, кожного дня приїжджали з обкому партії, і лякали нас ... обзивали лайкою, брудними словами ... казали, що то бандерівці зробили, що це не могла зробити радянська влада. Якщо ви не найдете жертви, то ми вас всіх арештуємо і засудимо» (Як проводили розкопки у 1989 році в Дем'яновому лазі біля Івано-Франківська).

Тогочасна влада та обласна комісія із розслідування сталінських злочинів мовчали, роблячи вигляд, що нічого надзвичайного не сталося. Ідеологи обкому партії поширювали чутки, що в лісі закопані німці, яких знищили радянські війська. Роман Круцик згадує: «...робилося все, щоб не дати людям дізнатися всієї правди. Наступного дня на місце захоронення прибула комісія, що складалася 3 високопоставлених членів обкому партії. I знову ми почули, що «цей злочин на совісті націоналістів або ж відступаючих німців». Але... Буквально на їхніх очах ми виявили в зотлілій одежі документ - копію вироку на громадянина Мишковського, виписану на бланку... НКВС!.. Чиновники знітилися. Згодом зуміли витребувати 3 архівів КДБ УРСР і його кримінальну справу, переконавшись, що така людина жила і була розстріляна як «ворог народу» (Зятьєв, 2010).

За свідченнями іншого очевидця: «Ще страшнішим було те, що у нижніх шарах могили лежали небіжчики, в яких були поламані руки й ноги. То були в'язні, яких привозили сюди вже мертвими зі Станіславської в’язниці: перед цим їх жорстоко катували, про що і свідчили скалічені кінцівки. Ті в'язні, які копали для них яму, водночас знімали 3 «автівок» мертвих і скидали до ями. Ну а потім вже розстрілювали і їх, засипаючи тіла землею. Дослідники знаходили грудні кістки людей $з$ правильними чотирикутними отворами, які доводили, що після пострілів у потилиці тіла проколювали багнетами...» (Зятьєв, 2010). Крім кісток, у розкопах знайшли масу артефактів: одяг, постоли, кулі, гаманці, гребінці, годинники, гудзики, зубні щітки, кляпи, мило, священицькі ложечки для причастя, документи - копії вироків, протоколів, квитанції. Все це звозилося до міліцейської лабораторії Івано-Франківська, що на вулиці імені Андрія Сахарова (за іронією долі, колишня їі назва «Чекістів»). (Кіпіані, 2010).

Після закінчення усіх необхідних досліджень 29 жовтня 1989 р. останки 524 людини, зокрема (151 жіночих, 359 чоловічих, серед них 76 осіб не досягли й 20-річного віку) урочисто перепоховали за християнським звичаєм у тридцяти трьох домовинах. Було встановлено прізвища лише 22 жертв (навіть не 5\%! - I. Ч.), а також імена дев’ятьох катів 3 місцевого НКВС. Звертає увагу кількість людей, які прийшли вшанувати жертв комуністичного режиму (за свідченнями очевидців їх було близько 500 тисяч), а також прониклива промова активіста Зиновія Думи під час перепоховання: «Люди, живі, чи зможемо ми зробити все, щоб ніколи не повторився Дем'янів Лаз з нашими дітьми чи внуками? Чи здатні ми подолати свій страх, об'єднатися в ім'я свободи, правди і добра? Чи станемо колись народом? Чи згодні ми утвердити наше неприйняття будьякого насильства, будь-якої диктатури, будь-якої проповіді ворожнечі і ненависті між людьми?» (Возняк, 2010: 27). І нині ця промова не втратила своєї актуальності.

Згодом зовсім поруч з'явилися ще дві могили, в одній - 1999 р. перепоховані останки 15 жертв, розстріляних органами НКВД на території ЗОШ №5 (кілька років тому там знову були знайдені людські кістки - I. Ч.), в іншій могилі 3 грудня 1991 р. - перепоховано останки 32 жертв режиму, закатовані і знайдені біля с. Посіч (це село було цілком знищене окупаційною владою) (Круцик, БРВ: 14-15). Всі п'ять могил утворюють центральне ядро архітектурно-ландшафтного комплексу, навколо них у вигляді кола висаджені туї.

Активістами міського осередку «Меморіал» (Олег Сараб, Зиновій Дума, Роман Круцик) окрім розкопок була проведена грунтовна збиральницька та дослідницька робота. Протягом літа 1989 р. Р. Круцик зміг зафіксувати півтора десятка свідчень мешканців сіл Павлівки, Пасічної, Рибного та ін. Серед інших, дослідник згадує про вкрай важливе коротке інтерв'ю 3 колишнім комсомольцем Володимиром Данилишиним, якого німці в 1941 р. змушували розкопувати могили. Той визнав, що бачив багато трупів: «між ними жінки і діти. Жінки в національній одежі, а чоловіки переважно в міській - камізельках». Знайдені 
гільзи були без маркування, щоб не залишати слідів. Декого, судячи з характерних ознак, добивали багнетами (Кіпіані, 2010).

За свідченнями очевидців тих подій, після розстрілів і захоронень у лісі три дні гуркотіла важка техніка, бульдозери розрівнювали грунт, трамбували землю, знищуючи сліди кривавих злочинів. 3 початком війни НКВС спішно нищив тих, хто мав бути знищений. Не було часу заводити кримінальні справи, робити дома обшуки, відбирати особисті речі. Ті нелюди робили те, що ще можна було зробити перед втечею... (Возняк, 2010: 24).

Зв'язки між регіональними осередками «Меморіалу» та «Руху» допомогли відшукати свідків та родичів зниклих безвісти та закатованих. Стало відомо, що убивали та ховали тут жителів не лише околиць Станіслава й навколишніх сіл, а також 3 Кутів, Коломиї, навіть віддалених сіл Снятинського району (с. Белелуї). Загалом на Прикарпатті відомо понад 70 місць масових поховань жертв комуністичного режиму (Добош, 2015).

Убивали та вивозили у Дем'янів лаз тих, хто відзначався свідомою громадянською позицією, як правило, представників інтелігенції, учителів, бібліотекарів, керівників читалень, священиків, тих, хто брав участь у створенні таких національних інституцій як «Сокіл», «Пласт», «Просвіта», людей із вищою освітою, в тому числі випускників європейських навчальних закладів. А їхніми карателями були обмежені й неосвічені люди. Так, другий секретар Тисменицького райкому Маслов мав «незакінчену нижчу», тобто не осилив навіть початкової школи. 327 голів райвиконкомів тільки семеро мали середню освіту. Найнижчий освітній ценз мали керівники райвідділів НКВС, НКДБ, начальники фінвідділів, прокурори й народні судді. За національністю вони майже всі були росіяни (Кіпіані, 2010). Більшість із закатованих, судячи зі залишків одягу і взуття, були незаможними, втім серед них були і священики, це вдалося ідентифікувати на підставі особистих речей, які не носили миряни.

У центрі меморіального комплексу височіє своєрідний пам'ятник закатованим жертвам - каплиця-дзвіниця (автори проекту - скульптор Василь Лендєл, та архітектор Олег Козак) (Круцик, БРВ: 5) конструктор Микола Матюшенко. Урочисте відкриття та освячення каплиці відбулося 5 листопада 1998 року. Відтоді там щонеділі проводяться богослужіння. Каплиця урочисто-білого кольору, центрична у плані, нижній ярус - пірамідальний, архітектура храму виконана в модерністичних формах, за силуетом дещо нагадує сакральні споруди Радослава Жука.
Завдяки своєму розташуванню у найвищій точці пагорбу Дем'янового Лазу вона проглядається здалеку.

Інтер'єр храму добре освітлюється завдяки вузьким вертикальним вікнам, що знаходяться у верхньому ярусі. Споруда завершується декоративною банею на чотирьох стовпах, тут $\epsilon$ також два дзвони, розміщені один над одним. Акцентом в інтер'єрі $є$ невеликий одноярусний, але урочистий іконостас, створений митцем Василем Хоминим у 2000-му р., замовником якого виступив тодішній мер міста Зиновій Шкутяк. Намісний ярус має 4 ікони - Богородиця 3 дитям, Христос, княгиня Ольга і князь Володимир, святі змальовані у повен зріст. Над царськими воротами - монументальна композиція «Тайної вечері». Столярні роботи виконували працівники фірми «XITA», декоративну різьбу Дмитро Каськів. Освячував іконостас владика Г. Війтишин, який благословив і самі проєкти. Для освячення каплиці та іконостасу було запрошено десять священників, відбулася також урочиста архієрейська служба Божа.

На вівтарній стіні розташовується велика композиція «Розп'яття». На стінах знаходиться кілька сакральних композицій зі зображенням Христа та Богородиці. Розписи підкупольного простору виконав художник Петро Боєчко.

У підвальному приміщенні каплиці на площі 92 кв. м. розміщено стаціонарну експозицію музею «Дем'янів Лаз». Вона розповідає про репресії комуністичного режиму на Прикарпатті у 1939-1941 рр., про історію пошуку та розкопок поховань, про людські долі, які опинилися в пекельних жорнах енкаведистської машини (Круцик, БРВ: 5). Дизайн-концепція експозиції розроблена відомим на Прикарпатті митцем Ростиславом Котерліним.

Важливе місце у формуванні експозиційного середовища займає діяльність дизайнерів. У вказаному музеї проектування й необхідні технічні роботи виконували дизайнери та працівники фірми «Реклама-центр». Так, хрест виконаний 3 прозорого пластику, в середині якого вмонтована точкова підсвітка, яка сприяє чіткому й детальному огляду експонатів. Всі стели, виконані 3 акрилового пластику способом друку, мають чорний фон, всі написи - молочного кольору. Для підсвітки використані лампи денного світла за принципом світильника. Музей також використовує власну підсвітку для стел і панно. Прозорі вітрини, в яких розміщуються артефакти та документи, також $з$ прозорого пластику, 3 підсвіткою. Отож із проєктного й технологічного аспектів, 
дизайнерами застосовуються новітні рекламні матеріали 3 метою створення сучасного візуально виразного дизайну виставкового простору.

Серед документів, що експонуються, - фотографії як закатованих так і їхніх мучителів, особисті речі, предмети побуту, гігієни, навіть недорогі прикраси. Зі слів очевидця Зиновія Думи, усі ці знахідки стали доказом злочинів, адже найголовнішим у тих розкопках було довести злочинний характер дій тодішньої окупаційної влади. За позолоченою пластиною на місці трепанації черепа встановили особу сотника УГА Григорія Голинського (Добош, 2015). Уперше в експозиції музею з'явилися списки працівників Станіславського УНКВС 1939-1941 pр., які тією чи іншою мірою були причетні до масового терору жителів Прикарпаття, які розміщуються на стелах. Один із розділів розповідає про створення на Прикарпатті товариств «Рух» та «Меморіал», які дали поштовх до дослідження тогочасних трагічних подій. Цікавими є документи, речі, які підтверджують діяльність цих товариств. Увагу відвідувачів привертає панорамне фото тюрми НКВС у м. Станіславові 1941 року. Поруч експонуються копії світлин із кримінальних справ, заведених органами НКВС на Павліну Вариводу, Юліана Бойдуника, Ярослава Мазуркевича. Усі ці люди були реабілітовані у 1996 році (Меморіальний комплекс «ДЕМ'ЯНІВ ЛАЗ»).

Центральною частиною музейної експозиції $\epsilon$ велике художнє панно «Дем'янів Лаз - відлуння «золотого» вересня» (його розміри бл. 2,5*7 м), авторами якого $є$ київські митці, члени НСХУ Левко Воєдило та Олесь Соловей (викладач Національної академії образотворчого мистецтва і архітектури (майстерня професора Миколи Стороженка). Художникам вдалося образотворчою мовою передали весь трагізм ситуації в Галичині початку Другої світової війни. Адже ціна «золотого вересня» для Галичини була жахливою: 3 осені 1939-го по осінь 1940 рр. за політичними ознаками, часто навіть без письмового обвинувачення, було репресовано близько $10 \%$ населення, 312 тисяч сімей. Понад один мільйон сто тисяч людей. А ще десятки тисяч українців, поляків, євреїв зникли без вісти. За чутками, їх розстрілювали десь неподалік. Довгі роки, де саме, було невідомо. (Кіпіані В., Композиційним центром панно $є$ «Гулульська мадонна». Жінка, що тримає на руках немовля, зображена у динамічній, драматичній позі, iii тіло болісно вигнулося, стримуване витками колючого дроту. Очевидно, художників вразили свідчення очевидців розкопок, коли було знайдено жінку в гуцульському народному вбранні, яка тримала на руках дитину, вони так і загинули обоє в обіймах... Мадонна зображена зі скорботним обличчям, вона притискає до грудей немовля, обмотане колючим дротом. Вони зображені на білому тлі - втіленні чистоти, безгрішності. Водночас, як і Богородиця, матір гордо зносить свої страждання, не полишаючи надію. I цю надію може дати біле тло як символ Божого світла. Уся земля під ногами катів і тілами убитих - червона, як знак страждання і мучеництва. Вважаємо, панно не залишить жодного відвідувача байдужим.

Кульмінацією експозиції є велика стела, на якій виписано прізвища та розміщено фотографії галичан, доля яких була зламана. За розміщення фотографій, експонатів, текстові матеріали відповідала заступник директора музею Оксана Романів, пошукову роботу в архівах проводив аспірант історичного факультету Київського національного університету ім. Т. Шевченка Сергій Жовтий. Особливого емоційного переживання додає розташована під стелою інсталяція символічної могили у вигляді хреста, на дні якої бачимо взуття, колючий дріт, рештки одягу та документів (Меморіальний комплекс «ДЕМ' ЯНІВ ЛАЗ»). Це також має глибокий символічний зміст: особисті речі неодмінно нагадують про невинних жертв, змушують ще раз задуматися про цінність людського життя. І незважаючи на те, що тоталітарна влада будь-якими засобами намагалася приховати власні злочини, ми маємо можливість відновити історичну справедливість, вшановувати закатованих краян.

До каплиці-дзвіниці ведуть широкі сходи. Недалеко від неї справа - статуя Богородиці, розміщена під куполом, який здіймається на колонах і має вигляд невеличкої ротонди. Встановлення таких скульптур $\epsilon$ характерним для регіону початку 2000-х років. Така скульптурна домінанта несе глибокий символічний смисл: Богородиця наче зустрічає тих, хто підіймається дорогою до каплиці, налаштовує на зосередженість та смиренність паломників.

Перед каплицею розташована велика стела, де міститься загальна інформація про розкопки та перепоховання 29 жовтня 1989 р., про жертв, яких вдалося ідентифікувати. Стела складається 3 металевої конструкції і з композитного пластикового листа. Територія навколо поховань і каплиці опоряджена декоративними рослинами, домінуючими в ландшафті $є$ ялини й туї. Парковою територією опікується Прикарпатський національний університет імені Василя Стефаника. До меморіального комплексу ведуть дві дороги, одна 3 яких має назву «Хресна дорога», саме по ній їхали ван- 
тажівки із закатованими людьми. Вздовж дороги встановлено 13 хрестів.

Цікавим, на жаль, не реалізованим проєктом пам'ятника жертвам Дем'янового Лазу є робота художника Михайла Зорія «Розстрілане серце України», макет якого створений 1989 р. після проведених розкопок та нині зберігається в експозиції музейного комплексу. Автор проєкту, пройшовши через горнило сталінського режиму, залишився незламним і свободолюбним. А свій біль та розпач він втілив у символічному серці, простріляному наскрізь трьома кулями, від яких залишилися три наскрізні отвори, з яких цівкою струменить кров патріотів і невинних жертв, наповнюючи чашу. Над серцем підноситься хрест - символ Христової жертви. Так, глибоко символічно митцеві вдалося передати роз'ятрену рану на серці України, якою досі залишаються злочини радянського тоталітаризму. Це своєрідне нагадування про те, що не повинні забувати прийдешні покоління, в пам'ять про мільйони невинних жертв терору.

Під час святкування 20-річчя розкопок, 3 нагоди відкриття музею відбулася, зокрема, і презентація книги Романа Круцика «Дем'янів Лаз» - книги, яка написана на основі документів, виявлених в архівах НКВС (Круцик, 2009). У ній містяться копії цих документів, фотографії останків, прізвища безневинних жертв. А ще - прізвища тих, хто був безпосереднім виконавцем злочинних наказів: подібних прецедентів, щоб відкрито вказувалися імена жертв і їхніх катів, в Україні ще не було... (Зятьєв, 2010).

Проведення розкопок, ексгумації і перепоховання останків жертв репресій на території
Івано-Франківщини відбулося в багатьох населених пунктах. Лише дозволів на проведення таких розкопок протягом 1090-х рр. видано владою для більш як 100 прикарпатських сіл і міст (Круцик, БРВ: 21). Останнім часом виявляються все нові знахідки, що свідчать про масові злочини радянської влади, як, наприклад знайдені тіла розстріляних жертв поблизу Єзупольської лікарні у 2014 р. (бл. 170 фрагментів останків!). Таким чином, на сьогодні перед дослідниками трагічних подій на Прикарпатті в 1939-1941рр. стоїть ще дуже багато запитань про долі тисяч людей, які загинули в той період (Круцик Р., БРВ:22).

Висновки. Отже, музей відбувся завдяки ентузіастам та спеціалістам, а також небайдужим людям; щонеділі на церковній службі у каплиці згадують загиблих, сюди приходять родичі та нащадки невинно закатованих, проводять екскурсії для учнів місцевих шкіл. Парковим комплексом опікується Прикарпатський національний університет імені Василя Стефаника. Музейний комплекс «Дем'янів Лаз», створений українськими художниками й дизайнерами відповідно до розуміння концепції функціонування сучасного музейного простору, є доволі виразним, сучасним, наочно втілює ідею збереження людської пам'яті про складні й жахливі сторінки національної істоpiї XX століття. Досвід такої роботи, зокрема, сучасних дизайнерських підходів до формування експозиційного середовища, $є$ цінним для створення і функціонування схожих музеїв людської пам'яті, роботи у цій царині належить провести ще дуже багато. На завершення ватро наголосити: потрібно пам'ятати історію, щоб уникнути колишніх помилок.

\section{СПИСОК ВИКОРИСТАНИХ ДЖЕРЕЛ}

1. Возняк Х. Меморіальний комплекс «Дем’янів Лаз». Курсова робота з історії мистецтва. Рукопис, Івано-Франківськ. $2010.41 \mathrm{c}$.

2. Добош Г. Дем'янів Лаз: «розкопані й закопані могили», 2015. режим достуny: http://www.radiosvoboda.org/ content/article/1848818.html (дата звернення: 20.09.2017).

3. Зятьєв С. Дем'янів Лаз, 2010. режим достуny: http://www.memorial.kiev.ua/genocyd-ukrajinciv/masovirozstrily/826-demjaniv-laz.html (дата звернення: 20.09.2017).

4. Кіпіані В. Дем'янів Лаз. Геноцид Галичини, 2010. режим достуny: http://www.istpravda.com. ua /reviews/2010/09/6/454/ (дата звернення: 27.09.2017).

5. Круцик Р. Дем'янів Лаз: геноцид Галичини. Жертвам комуністичного терору 1939-1941рр. на Прикарпатті присвячується. Київ : Простір, 2009. 349 с.

6. Круцик Р. Меморіальний комплекс Дем’янів Лаз. БРВ, БМВ. 24 с.

7. Меморіальний комплекс «ДЕМ'ЯНІВ ЛАЗ» Філіал Обласного музею визвольної боротьби імені Степана Бандери: режим достуny: http://www.karpaty.info/ua/ uk/if/fr/ivano-frankivsk/museums/memory/ (дата звернення: 28.09.2017).

8. Як проводили розкопки у 1989 році в Дем'яновому лазі біля Івано-Франківська : режсим достуny: http://zik.ua/ tv/video/14241/ (дата звернення: 28.09.2017). 


\section{REFERENCES}

1. Voznyak H. Memorialnyy kompleks «Demyaniv Laz». Kursova robota z istorii mystetstva [Course work on art history]. Manuscript, Ivano-Frankivsk, 2010. [in Ukrainian].

2. Dobosh H. «Demyaniv Laz» «rozkopani y zakopani mohyly», 2015. URL: http://www.radiosvoboda.org/content/article/1848818.html [in Ukrainian].

3. Zyatyev S. Demyaniv Laz, 2010. URL: http://www.memorial.kiev.ua /genocyd-ukrajinciv/masovi-rozstrily/826-demjaniv-laz.html [in Ukrainian].

4. Kipiani V. Demyaniv Laz. Henotsyd Halychyny. [Demyaniv Laz. Genocide of Halychyna], 2010. URL : http://www.istpravda.com.ua /reviews/2010/09/6/454/ [in Ukrainian].

5. Krutsyk R. Demyaniv Laz. Henotsyd Halychyny. Zhertvam komunistychnoho teroru 1939-1941 rr. na Prykarpatti prysvyachuetsya. [Demyaniv Laz. Genocide of Halychyna. It is dedicated to the victims of the communist terror of 19391941 in Prykarpattya ]. Kyiv : Prostir, 2009. 349 p. [in Ukrainian].

6. Krutsyk R. Memorialnyy kompleks Demyaniv Laz. [The Memorial complex Demyaniv Laz]. BRV, BMV. 24 p. [in Ukrainian].

7. Memorialnyy kompleks «Demyaniv Laz» Filial oblasnoho muzeyu vyzvolnoyi borotby imeni Stepana Bandery [The Memorial complex Demyaniv Laz Branch of the Stepan Bandera Regional Museum of the Liberation Struggle]. URL: http://www.karpaty.info/ua/ uk/if/fr/ivano-frankivsk/museums/memory/ [in Ukrainian].

8. Yak provodyly rozkopky u 1989 rotsi v Demyanovomu Lazi bilya Ivano-Frankivska [How excavations were carried out in 1989 in Demyaniv Laz near Ivano-Frankivsk]. URL: http://zik.ua/tv/video/14241/ [in Ukrainian]. 